\title{
New Insights on Disintegrin-Receptor Interactions: Eristostatin and Melanoma Cells
}

\author{
M.A. McLane M.A. Kuchar C. Brando D. Santoli \\ C.A. Paquette-Straub M.E. Miele
}

Department of Medical Technology, University of Delaware, Newark, Del., and The Wistar Institute, Philadelphia, Pa., USA

\section{Key Words}

Integrin · Disintegrin • Eristostatin •

Melanoma $\cdot$ Metastasis $\cdot$ NK cells

\begin{abstract}
Viper venom disintegrins have been used frequently to study the cellular receptors which characterize various types of cells, including platelets, endothelial cells and cancer cells. While the majority of such analyses have pointed to involvement of integrin receptors $\alpha v \beta 3$, $\alpha 5 \beta 1$ or $\alpha$ llb $\beta 3$, this may not always be so. Eristostatin, from Eristocophis macmahoni, is a potent inhibitor of ADPinduced platelet aggregation as well as of human and murine melanoma metastases in mouse model systems. This disintegrin requires an RGDW motif, as well as an intact C-terminus, in order to interact with both platelets and four different types of melano-
\end{abstract}

\begin{tabular}{ll}
\hline KARGER & ( 2002 S. Karger AG, Basel \\
Fax +41 61 306 1234 $301-0147 / 01 / 0316-0177 \$ 17.50 / 0$ \\
$\begin{array}{l}\text { E-Mail karger@karger.ch } \\
\text { www.karger.com }\end{array}$ & $\begin{array}{l}\text { Accessible online at: } \\
\text { www.karger.com/journals/hae }\end{array}$
\end{tabular}

ma cells. Eristostatin causes nonmetastatic SBc12 melanoma cells to show higher susceptibility to specific killing by NK-like TALL104 cells. While it is known that eristostatin binds to $\alpha$ llb $\beta 3$ on platelets, the receptor with which eristostatin binds to the melanoma cells has not yet been identified.

Copyright $@ 2002$ S. Karger AG, Basel

\section{Introduction}

Disintegrins are low molecular weight, cysteine-rich proteins isolated from viper venom [1]. Previous investigations have demonstrated that these proteins interact with many types of cells, such as platelets [2], neutrophils [3], human umbilical vein [4] and bovine capillary [5] endothelial cells, and many types of cancer cells, including breast [6], neuroglial [7], bladder [8] and melanoma [9]. Whenever

\footnotetext{
Mary Ann McLane, PhD, CLS(NCA)

Department of Medical Technology

McKinly Lab 057, University of Delaware

Newark, DE 19716 (USA), Tel. +1 3028318737 (office)

Fax +1 302831 4180, E-Mail mclane@udel.edu
} 
the investigations have attempted to identify the receptor through which the interaction is achieved, an integrin is usually involved. This is understandable since all disintegrins possess binding motifs (RGD, KGD, MVD, MLD, VGD) similar to those found in native ligands, such as fibronectin, fibrinogen and VCAM-1 [10-12]. Disintegrins, as a family of proteins, simultaneously share significant sequence homology and cysteine arrangement, yet demonstrate substantial diversity in their binding interactions with cellular integrins. We previously demonstrated that certain nonRGD motifs present in these adhesive ligands will also contribute to their binding selectivity for $\alpha \operatorname{IIb} \beta 3, \alpha v \beta 3$ and $\alpha 5 \beta 1$ integrins [13]. We have used a panel of recombinant mutants of eristostatin (based on the native protein from Eristocophis macmahoni) to investigate whether the binding motifs required for interacting with 'normal' cells are also required with transformed, cancerous cells. We also hypothesize a mechanism for the ability of eristostatin to inhibit melanoma cell metastasis.

\section{Material and Methods}

\section{Chemicals and Media}

Standard laboratory chemicals were obtained from Sigma (St. Louis Mo., USA). Eight-chambered coverslip slides were from Nalge Nunc (Naperville, Ill., USA). Dulbecco's media and PBS were obtained from Mediatech (Herndon, Va., USA). Fetal calf serum was from GibcoBRL (Rockville Md., USA). $\mathrm{H}_{3}{ }^{51} \mathrm{CrO}_{4}$ was obtained from Perkin-Elmer (Boston, Mass., USA). Antibodies against $\alpha 4$ integrin subunit were purchased from Immunotech (Marseille, France) and antibodies against CD48, CD27, CD70, CD137, CD137-ligand, CD134, and FAS were purchased by Pharmigen (San Diego, Calif., USA). For flow cytometry analysis, fluorescinated secondary antibodies were purchased from Organon Tecnika Corporation (Durham, N.C., USA).
Cells Used

Human melanoma cell lines 1205-LU, WM164 and $\mathrm{SBc} 12$ were kindly provided by Dr. Meenhard Herlyn (The Wistar Institute, Philadelphia, Pa., USA), while C8161 and MV3 cells were obtained from Danny Welch (Penn State University, Hershey, Pa., USA) and Stefan Niewiarowski, (Temple University, Philadelphia, Pa., USA), respectively. Cells were cultured in Dulbecco's Modified Eagle's medium/F12 containing $L$-glutamine and supplemented with $10 \%$ fetal calf serum (FCS). Cells were grown at $37^{\circ} \mathrm{C}, 5 \% \mathrm{CO}_{2}$, detached using $2 \mathrm{mmol} / 1$ EDTA and resuspended in Dulbecco's phosphate-buffered saline. Cytotoxic cell line TALL-104 (MHC-nonrestricted, CD8+, CD56+, CD16-, CD161+) were grown in Iscove's Modified Dulbecco's Medium, supplemented and grown as above.

\section{Preparation of Disintegrins}

Wild-type eristostatin and five mutations listed in table 1 were expressed in Escherichia coli as described previously [13]. ADP-induced platelet aggregation was used to screen each disintegrin, and the $\mathrm{IC}_{50}$ values obtained agreed with those previously published [13]. FITC-labeling of eristostatin was performed using a Fluorotag conjugation kit from Sigma, following the manufacturer's directions. The ratio of fluorescence to protein of the labeled disintegrin was 1:6.

\section{Binding Inhibition}

Each human melanoma cell line (3E5) was incubated with buffer or unlabeled disintegrin (500$3,000 \mathrm{nM}$ ). Without washing, the cells were then stained with FITC-labeled eristostatin (for 1205-LU, WM164, C8161) or FITC-labeled anti- $\alpha 4$ (for MV3). All data were acquired on a Zeiss inverted $100 \mathrm{M}$ Axioskop equipped with a Zeiss 510 LSM confocal microscope and a krypton-argon laser. Each binding pattern was rated from zero (no inhibition) to +3 (complete inhibition), depending on how much the disintegrin inhibited the binding of the FITC-labeled protein.

\section{Flow Cytometry Analysis}

$\mathrm{SBc} 12$ melanoma cells were incubated for 3 days in the presence or absence of $500 \mathrm{n} M$ eristostatin. After washing, the cells were stained with primary antibodies to cell surface markers, washed and probed with FITC-conjugated secondary antibody. Flow analysis was performed on an Epics XL flow cytometer, and nonspecific fluorescence (using $1 \mathrm{mg}$ FITC-albumin) showed less than 0.5 fluorescence units. 
Table 1. Mutations made in RGD loop and C-terminus of eristostatin or echistatin

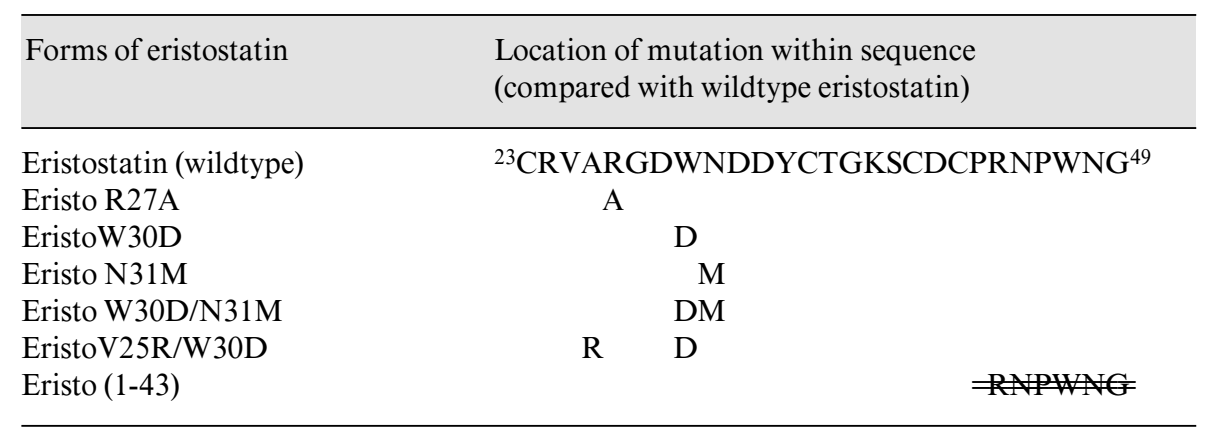

For each mutation, the amino acid substitution is placed under its corresponding wildtype residue. Those motifs which are removed are indicated by a double crossout.

\section{Cell Cytotoxicity}

Sensitivity of human melanoma SBc12 cells, incubated overnight with $500 \mathrm{n} M$ eristostatin or media control, to the cytotoxic action of TALL-104 cells was tested in an $18 \mathrm{~h}{ }^{51} \mathrm{Cr}$ release assay, performed as previously described [14]. Briefly, SBc12 target cells were resuspended at $1 \mathrm{E} 6 / \mathrm{ml}$ in PBS and labeled for $1 \mathrm{~h}$ at $37^{\circ} \mathrm{C}$ with $0.1 \mathrm{mCi}$ of $\mathrm{H}_{3}{ }^{51} \mathrm{CrO}_{5}$. After washing, cells were resuspended at $1 \mathrm{E} 4 / 50 \mu \mathrm{l}$ and incubated at $37^{\circ} \mathrm{C}$ in $10 \% \mathrm{CO}_{2}$ with serially diluted effector TALL-104 cells. After $18 \mathrm{~h}$, cell supernatant was collected, and released radioactivity was measured with a gamma counter. Percent of specific radioactivity was calculated as: sample radioactivity - spontaneous release/ total radioactivity (Triton-lysed cells) - spontaneous release $\times 100$.

\section{Results and Discussion}

Eristostatin is unique among the venomderived disintegrins for a number of reasons. It is a potent inhibitor of ADP-induced platelet aggregation $\left(\mathrm{IC}_{50}=70 \mathrm{nM}\right)$, and binds $\alpha \operatorname{IIb} \beta 3$ integrin with a $\mathrm{K}_{\mathrm{d}}$ of $18 \mathrm{n} M$, whether the platelets are resting or activated by ADP or thrombin [2]. It has been shown to inhibit lymphocyte infiltration of pancreatic islets in nonobese diabetic mice [Clara Brando, unpubl. obs.], and is able to inhibit melanoma metastasis in an in vivo model of experimental metastasis, using either murine $[15,16]$ or human [9] melanoma cells. It shares an integrin selectivity property with another disintegrin, barbourin [17], since it has been shown to interact with cells primarily through the integrin $\alpha \operatorname{IIb} \beta 3$ [2], although Danen et al. [9] did demonstrate a possible binding to $\alpha 4 \beta 1$ on MV3 melanoma cells. In contrast to most other disintegrins, however, eristostatin does not interact with $\alpha v \beta 3$ or $\alpha 5 \beta 1$ [13]. It is curious that the murine melanoma cells used in the experimental metastasis assays (BL16F10, BL16F1) showed a strong expression of $\beta 3$, but the human MV3 cells did not. This would suggest that eristostatin may not use $\alpha \operatorname{IIb} \beta 3$ consistently, if at all, in its interactions with the melanoma cells whose metastasis it inhibits. As the first step in determining the molecular mechanism used by eristostatin to inhibit human melanoma metastasis, we used our panel of recombinant eristostatin mutants (table 1) to demonstrate which motifs within eristostatin are most critical for the in vitro interaction of eristostatin with four human melanoma cell lines (MV3, C8161, 1205-LU, WM164) by confocal microscopy 
Table 2. Summary of all cell lines for inhibition of binding by recombinant disintegrins

\begin{tabular}{lrccc}
\hline Disintegrin & 1205-LU & WM164 & C8161 & MV3 \\
\hline Eristostatin & +2 & +3 & +3 & +3 \\
ErR27A & 0 & 0 & 0 & 0 \\
ErW30D & +2 & +2 & +2 & 0 \\
ErV25R/W30D & +2 & +2 & +2 & +1 \\
ErW30D/N31M & +3 & +3 & +3 & 0 \\
ErN31M & +3 & +3 & +3 & 0 \\
Eristostatin(truncated) & 0 & 0 & 0 & 0 \\
\hline
\end{tabular}

Each human melanoma cell line (3E5) was incubated with buffer or the indicated disintegrin (500-3000 $\mathrm{n} M$ ). Without washing, the cells were then stained with FITC-labeled eristostatin (for 1205-LU, WM164, C8161) or FITC-labeled anti- 44 (for MV3), and observed by confocal microscopy. Each binding pattern was rated from 0 (no inhibition) to +3 (complete inhibition), depending on how much the disintegrin inhibited the binding of the FITC-labeled protein. The data are representative of a minimum of 2 identical experiments. (table 2). The four melanoma cell lines were used to determine whether the interaction of eristostatin with human melanoma cells was unique to MV3. In fact, eristostatin bound to all four cell types. This was directly shown with 1205-LU, WM164 and C8161 cells through confocal microscopy using FITCeristostatin. For MV3 cells, we demonstrated the interaction of eristostatin by showing a dose-dependent inhibition of the binding of anti- $\alpha 4$, confirming the findings of Danen et al. [9] that eristostatin interacts with $\alpha 4 \beta 1$ on these cells. As summarized in table 2, binding to 1205-LU, WM164, and C8161 melanoma cells requires an RGD sequence and an intact C-terminus. Asparagine is not needed in the RGD loop of eristostatin for binding to these cells. Surprisingly, methionine at position RGDXX enhances the ability of eristostatin to bind. For MV3 melanoma cells, an $\mathbf{R G D}$ sequence, an intact C-terminus, and both asparagine and tryptophan in the RGD loop of eristostatin are required. We hypothesize that eristostatin uses the same molecular mecha- nism to bind to $1205-\mathrm{LU}$, WM164, and C8161 melanoma cells. However, the melanoma cell receptor by which eristostatin accomplishes this interaction is as yet unidentified. Based on the pattern of eristostatin mutation results, we propose that the mechanism at work in its interactions with MV3 cells is different from the one used in binding to 1205LU, WM164, and C8161 cells.

In order to study the consequences of the binding of eristostatin to melanoma cells, we first incubated SBc12 human melanoma cells $\pm 4000 \mathrm{n} M$ eristostatin for 5 days, and observed no difference between the control and treated cells in cell count or gross appearance, confirming the findings of Danen et al. [9] and Morris et al. [16] (data not shown). We then tested whether the presence of eristostatin would make a difference in the ability of cytotoxic cells to kill the SBc12 melanoma cells. As shown in figure 1, TALL-104 cytotoxic cells [18] are capable of killing the SBc12 melanoma cells, in a dose-dependent fashion, without the presence of eristostatin. However, 


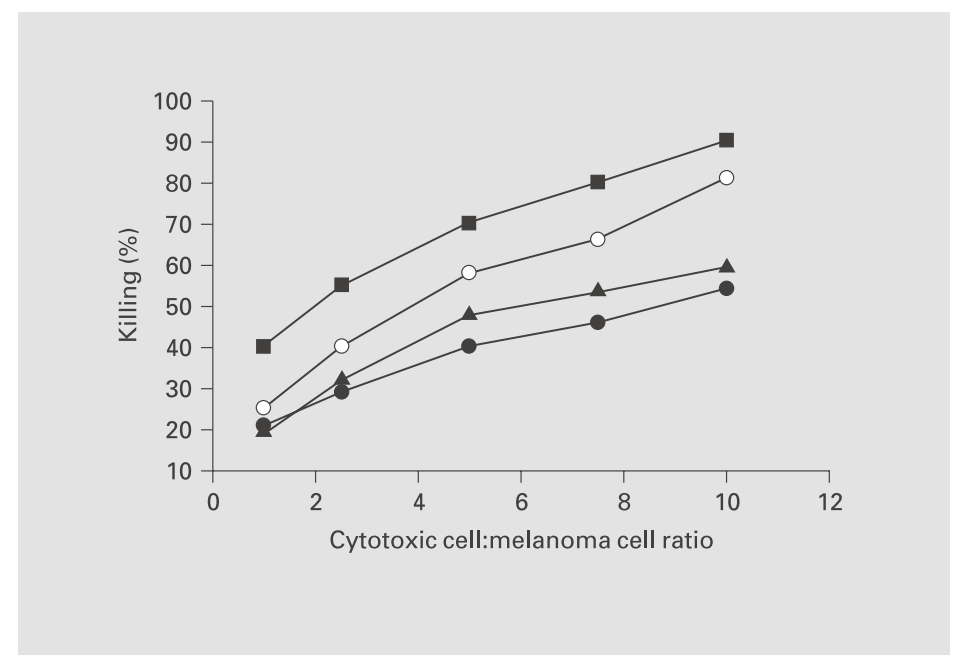

Fig. 1. Human melanoma SBc12 cells were incubated in the presence or absence of eristostatin for 3 days at $37^{\circ} \mathrm{C}$. After washing, the cells were counted and $10^{6}$ cells were suspended in media to which was added $100 \mu \mathrm{Ci} \mathrm{H}_{3}{ }^{51} \mathrm{CrO}_{4}$ for $1 \mathrm{~h}$. After washing with cold, complete media, these 'target' cells were distributed in 96-well plates, incubated with serial dilutions of effector cells: MHC-nonrestricted TALL-104 cells (CD8+, CD56+, CD16-, CD161+), which had been similarly incubated with or without eristostatin. After overnight incubation, the supernatant was harvested and the released radioactivity was counted with a gamma counter. Calculation of percent killing was expressed as: sample radioactivity - spontaneous release/total radioactivity (Triton-lysed cells) - spontaneous release $\times 100$. Data shown are representative of three identical experiments. = Untreated cytotoxic cell $/$ melanoma cell; $\boldsymbol{\Delta}=$ treated cytotoxic cell, untreated melanoma cell; $O=$ treated cytotoxic cell, treated melanoma cell; $\boldsymbol{\square}=$ untreated cytotoxic cell, treated melanoma cell. when the melanoma cells are incubated with eristostatin, TALL-104 cells show a 2-fold increased cytotoxic effect. One possible explanation is that incubation with eristostatin increases the expression of receptors for cytotoxic substances, secreted by effector cells, on the membrane of the target cell. Thus SBc12 were screened for the presence of Fas, CD27, CD134, CD137, and CD137-L by flow analysis. No differences were found between eristostatin-treated and control SBcl2 cells.

Another explanation could be that costimulatory molecules for the process of killing are modulated by eristostatin. Thus, cells were analyzed for the presence of $\mathrm{CD} 48$, ligand for 2B4, a costimulatory molecule expressed by cytotoxic cells [19]. Expression of CD48 is not affected by treatment with eristostatin. Studies are under way to identify the molecule with which eristostatin binds on these melanoma cells, and the intracellular consequences of this interaction. 


\section{References}

1 McLane MA, Marcinkiewicz C, Vijay-Kumar S, Wierzbicka-Patynowski I, Niewiarowski S: Viper venom disintegrins and related molecules. Proc Soc Exp Biol Med 1998; 219:109-119.

2 McLane MA, Kowalska MA, Silver L, Shattil SJ, Niewiarowski S: Interaction of disintegrins with the alpha IIb beta 3 receptor on resting and activated human platelets. Biochem J 1994;301:429-436.

3 Coelho AL, de-Freitas MS, Oliveira CA, Moura NV, Zingali RB, Barja FC: Effects of jarastatin, a novel snake venom disintegrin, on neutrophil migration and actin cytoskeleton dynamics. Exp Cell Res 1999; 251:379-387.

4 Juliano D, Wang Y, Marcinkiewicz C, Rosenthal LA: Disintegrin interaction with alpha $\mathrm{V}$ beta 3 integrin on human umbilical vein endothelial cells: Expression of ligand-induced binding site on beta 3 subunit. Exp Cell Res 1996;225:132142.

5 Kang IC, Lee YD, Kim DS: A novel disintegrin salmosin inhibits tumor angiogenesis. Cancer Res 1999;59: 3754-3760.

6 Zhou Q, Hu P, Ritter MR, Swenson $\mathrm{SD}$, Argounova S, Epstein AL, Markland FS: Molecular cloning and functional expression of contortrostatin, a homodimeric disintegrin from southern copperhead snake venom. Arch Biochem Biophys 2000;375:278-288.
7 Abrass CK, Berfield AK, Andress DL: Heparin binding domain of insulin-like growth factor binding protein-5 stimulates mesangial cell migration. Am J Physiol 1997;273: F899-F906.

8 Zhou Q, Nakada MT, Brooks PC, Swenson SD, Ritter MR, Argounova S, Arnold C, Markland FS: Contortrostatin, a homodimeric disintegrin, binds to integrin alphavbeta5. Biochem Biophys Res Commun 2000;267:350-355.

9 Danen EH, Marcinkiewicz C, Cornelissen IM, Van KA, Pachter JA, Ruiter DJ, Niewiarowski S, Van MG: The disintegrin eristostatin interferes with integrin alpha 4 beta 1 function and with experimental metastasis of human melanoma cells. Exp Cell Res 1998;238:188-196.

10 Pytela R, Pierschbacher MD, Argraves S, Suzuki S, Ruoslahti E: Arginine-glycine-aspartic acid adhesion receptors. Methods Enzymol 1987; 144:475-489.

11 Plow EF, Pierschbacher MD, Ruoslahti E, Marguerie G, Ginsberg MH: Arginyl-glycyl-aspartic acid sequences and fibrinogen binding to platelets. Blood 1987;70:110-115.

12 Marcinkiewicz C, Calvete JJ, Marcinkiewicz MM, Raida M, Vijay KS, Huang Z, Lobb RR, Niewiarowski S: EC3, a novel heterodimeric disintegrin from Echis carinatus venom, inhibits alpha4 and alpha5 integrins in an RGD-independent manner. J Biol Chem 1999;274:12468-12473.

13 Wierzbicka P, Niewiarowski S, Marcinkiewicz C, Calvete JJ, Marcinkiewicz MM, McLane MA: Structural requirements of echistatin for the recognition of alpha(v)beta(3) and alpha(5)beta(1) integrins. $\mathrm{J}$ Biol Chem 1999;274:37809-37814.
14 Rosenberg SA, Packard BS, Aebersold PM, Solomon D, Topalian SL, Toy ST, Simon P, Lotze MT, Yang JC, Seipp CA: Use of tumor-infiltrating lymphocytes and interleukin-2 in the immunotherapy of patients with metastatic melanoma. A preliminary report. N Engl J Med 1988;319:1676-1680.

15 Beviglia L, Stewart GJ, Niewiarowski S: Effect of four disintegrins on the adhesive and metastatic properties of B16F10 melanoma cells in a murine model. Oncol Res 1995;7:720.

16 Morris VL, Schmidt EE, Koop S, MacDonald IC, Grattan M, Khokha R, McLane MA, Niewiarowski S, Chambers AF, Groom AC: Effects of the disintegrin eristostatin on individual steps of hematogenous metastasis. Exp Cell Res 1995;219: 571-578.

17 Scarborough RM, Rose JW, Hsu MA, Phillips DR, Fried VA, Campbell AM, Nannizzi L, Charo IF, Barbourin A: GPIIb-IIIa-specific integrin antagonist from the venom of Sistrurus m. barbouri. J Biol Chem 1991;266:9359-9362.

18 Cesano A, Santoli D: Two unique human leukemic T-cell lines endowed with a stable cytotoxic function and a different spectrum of target reactivity analysis and modulation of their lytic mechanisms. In Vitro Cell Dev Biol 1992;28A: 648656.

19 Nakajima H, Colonna M: 2B4: An $\mathrm{NK}$ cell activating receptor with unique specificity and signal transduction mechanism. Hum Immunol 2000;61:39-43. 